\title{
KARAKTER MORFOLOGI DAN ANATOMI PISANG DIPLOID DAN TRIPLOID
}

\author{
ARi SunANDAR, Adi PASAH KaHAR
}

Fakultas Keguruan dan Ilmu Pendidikan, Universitas Muhammadiyah Pontianak, Jalan Ahmad Yani No. 111 Pontianak 78124

\section{A B S T R A C T}

Indonesia is the center of origin of bananas, and also the center of diversity with approximately more than 325 banana cultivars were found in Indonesia. The anatomical feature is essential as a basis for classification as well as the morphological feature. This research aimed to describe the morphological and anatomical characteristics of diploid Musa balbisiana and triploid Musa paradisiaca 'Kepok' bananas. Morphological characterizations were conducted according to the IPGRI descriptors for bananas (Musa spp.). Musa paradisiaca 'Kepok' was collected from Pontianak West Kalimantan and Musa balbisiana was collected from Nipah Panjang village Kubu Raya district West Kalimantan. The root, petiole, and leaf were dissected from banana samples for anatomical preparation. The microscope slide was prepared using paraffin method, stained with $1 \%$ safranine and $1 \%$ alcian blue. The anatomical characteristics of root and petiole of diploid Musa balbisiana and triploid Musa paradisiaca 'Kepok' were considerably similar. The difference between diploid and triploid banana leaf anatomy was the number of hypodermal layers. These sort of anatomical characterization could be applied as a reference for banana cultivars breeding.

KEY WORDS:anatomy characteristic, diploid, morphology characteristic, paraffin method, triploid

Penulis korespondensi:ARI SUNANDAR | email:arisunandar@unmuhpnk.ac.id Dikirim:08-12-2017 | Diterima:01-03-2018

\section{PENDAH UL UAN}

Pisang budidaya yang ada sekarang dipercaya berasal dari Musa balbisiana dan Musa acuminata (Simmonds \& Shepherd, 1955). Kedua species ini merupakan pisang diploid dengan grup genom BB (M. balbisiana) dan AA ( $M$. acuminata). Evolusi menyebabkan fertilitas bunga yang tinggi menurun dan kemampuan menghasilkan biji pada pisang diploid berubah menjadi steril dan sedikit menghasilkan biji (Megia, 2005).

Keanekaragaman pisang dapat dilihat dari rasa, bentuk, dan warna daging buah. Species dan kultivar pisang di Indonesia belum semua diklasifikasikan (Sumardi \& Wulandari, 2010). Pendekatan molekuler dan kariotipe kromosom telah digunakan untuk menggambarkan hubungan kekerabatan pada beberapa species pisang (Retnoningsih, 2009; Liu et al., 2010; Ahmad et al., 2014). Selain pendekatan molekuler dan kariotipe kromosom, pendekatan anatomi dapat digunakan untuk menggambarkan hubungan kekerabatan pada tanaman. Shokefun et al., (2016) melaporkan bahwa karakter anatomi daun dapat digunakan untuk menggambarkan hubungan kekerabatan pada beberapa species Microcos Linn. sect. Eumicrocos Burret. Kelimpahan, distribusi, dan tipe trikoma merupakan karakter pembeda pada Solanum sect. Polytrichum (Silva \& Agra, 2011).

Set kromosom pada pisang budidaya dapat berupa dioloid, triploid, atau tetraploid (Megia, 2005). Pada kebanyakan tanaman budidaya, peningkatan jumlah set kromosom akan meningkatkan produktivitas tanaman. Pisang Ambon (AAA) misalnya, memiliki tandan dan buah yang lebih besar dibandingkan pisang mas (AA) (Simmonds, 1966). Level ploidi tidak hanya berpengaruh pada karakter morfologi tetapi juga pada karakter anatomi. Padoan et al. (2013) melaporkan bahwa sel stomata pada jeruk triploid lebih besar dari pada sel stomata jeruk diploid. Sumardi \& Wulandari (2010) melaporkan bahwa ukuran dan jumlah stomata, jumlah lapisan hypodermal, struktur dan jumlah palisade parenkim, ukuran aerenkim pada petiol dan mesofil daun berbeda antara pisang diploid (M. acuminata 'Penjalin' dan M. balbisiana 'Khlutuk Warangan') dan pisang triploid (M. acuminata 'Ambon Warangan', $M$. paradisiaca 'Raja Nangka', dan $M$. paradisiaca 'Khlutuk Susu').

Tujuan dari penelitian ini adalah mendeskripsikan karakter morfologi dan anatomi pisang diploid $(M$. balbisiana) dan pisang triploid (M. paradisiaca 'Kepok'). Karakter anatomi sangat penting sebagai data pendukung untuk klasifikasi dan upaya peningkatan kualitas pisang budidaya di masa depan.

\section{ME T O D E}

Sampel pisang diploid (M. balbisiana) diambil dari Desa Nipah Panjang, Kecamatan Batu Ampar, Kabupaten Kubu Raya. Sedangkan sampel pisang triploid (M. paradisiaca 'Kepok') diambil di Kota Pontianak. Karakter morfologi kedua jenis pisang didokumentasikan menggunakan kamera digital. Karakterisasi morfologi pisang diploid dan triploid mengikuti panduan pada 'Descriptors for Banana (Musa spp.)' (IPGRI, 1996). Karakter morfologi yang diamati meliputi:karakter pseudostem, karakter petiol, karakter daun, karakter tangkai bunga (penduncle), karakter 'jantung' pisang, karakter bunga, karakter buah, dan khusus untuk pisang diploid, karakter biji juga diamati.

Preparat anatomi organ vegetative (akar, petiole, dan daun) pisang diploid dan triploid dibuat menggunakan metode paraffin. Akar, petiole, dan daun difiksasi pada larutan FAA selama 24 jam. Akar, petiole, dan daun selanjutnya didehidarasi dan dijernihkan menggunakan seri larutan Johansen I-VII (Johansen, 1940), ditanamkan pada lilin paraffin, dan dipotong menggunakan mikrotom putar dengan ketebalan $10 \mu \mathrm{m}$. Potongan akar, petiole, dan daun selanjutnya diwarnai dengan safranin $2 \%$ dan alcian blue $1 \%$, dan diamati menggunakan mikroskop cahaya. 


\section{HASIL DAN PEMBAHASAN}

Pseudostem M. balbisiana (diploid) berwarna hijau kekuningan, tipe petiole margins curved inward; bentuk pangkal daun satu sisi membulat dan sisi lainya runcing, warna permukaan atas dan bawah daun hijau, permukaan dorsal tulang daun berwarna hijau cerah dan permukaan ventral tulang daun berwarna hijau; panjang tangkai bunga (penduncle) 30-40 $\mathrm{cm}$, lebar 4,0-4,5 cm, warna hijau tua; bentuk jantung pisang intermediate, membulat, jumlah braktea yang terbuka dua atau lebih, braktea tidak menggulung; tepal majemuk berwarna cream, lobe tepal majemuk berwarna kuning, warna tepal bebas putih transparan, oval, triangular, kedudukan tangkai putik terhadap tepal majemuk sama tinggi, lurus; jumlah buah dalam satu sisir 7-14 buah, panjang buah 6-7 cm, lurus, lengthily pointed, persistent style; permukaan biji berkerut, berbentuk bulat, berwarna coklat (Table 1 dan Gambar 1).

Terdapat perbedaan karakter warna pseudostem, tipe petiole, bentuk jantung pisang, bentuk ujung braktea, bentuk ujung tepal bebas, dan bentuk ujung buah antara $M$. balbisiana pada penelitian ini dengan $M$. balbisiana di Jawa dan Sulawesi. Warna pseudostem $M$. balbisiana di pulau Jawa berwarna hitam-keunguan dan hijau, tipe petiole margin overlapping, bentuk jantung pisang ovoid, bentuk ujung braktea membulat dan terbelah, bentuk ujung tepal bebas triangular atau seperti jarum, bentuk ujung buah runcing (Hapsari, 2014). Pseudostem M. balbisiana di Sulawesi berwarna coklat keunguan, tipe petiole curved inward, jantung pisang berbentuk ovoid, bentuk ujung braktea intermediate, bentuk ujung tepal bebas triangular, dan bentuk ujung buah tumpul (Sulistyaningsih et al., 2014).

Musa paradisiaca 'Kepok' (triploid) memiliki pseudostem yang berwarna hijau, tipe petiole straight with erect margins; bentuk pangkal daun kedua sisi membulat, warna permukaan atas daun hijau tua dan bawah daun hijau, permukaan dorsal tulang daun berwarna hijau cerah dan permukaan ventral tulang daun berwarna hijau; panjang tangkai bunga (penduncle) $41 \mathrm{~cm}$, lebar 3,5 cm, warna hijau; bentuk jantung pisang ovoid, membulat dan terbelah, jumlah braktea yang terbuka satu, braktea tidak menggulung; tepal majemuk berwarna cream, lobe tepal majemuk berwarna kuning, warna tepal bebas putih transparan, oval, triangular, kedudukan tangkai putik terhadap tepal majemuk lebih tinggi, melengkung pada bagian pangkal; jumlah buah dalam satu sisir 13 buah, panjang buah $9 \mathrm{~cm}$, lurus, tumpul, dasar tangkai bunga menonjol (Tabel 1 dan Gambar 2).

Tabel 1. Karakter morfologi Musa balbisiana dan Musa paradisiacal 'Kepok'

\begin{tabular}{|c|c|c|}
\hline Karakter Morfologi & Musa balbisiana (BB) & Musa paradisiaca 'Kepok' (ABB) \\
\hline Leaf habit & Tegak & Tegak \\
\hline Warna Pseudostem & Hijau Kekuningan & Hijau \\
\hline Warna cairan batang & Seperti Air & Seperti Air \\
\hline Posisi anakan & Tumbuh Membentuk Sudut & Tumbuh Vertical \\
\hline Petiol canal leaf III & Margins curved inward & Straight with erect margins \\
\hline Panjang Daun (cm) & $120-157$ & $1.21-2.1$ \\
\hline Lebar Daun $(\mathrm{cm})$ & $36-56$ & $49-64$ \\
\hline Warna Permukaan Atas Daun & Hijau & Hijau Tua \\
\hline Warna Permukaan Bawah Daun & Hijau & Hijau \\
\hline Bentuk Pangakal Daun & One side rounded, one pointed & Both sides rounded \\
\hline Warna Permukaan Dorsal Tulang Daun & Hijau cerah & Hijau cerah \\
\hline Warna Permukaan Ventral Tulang Daun & Hijau & Hijau \\
\hline Panjang Peduncle (cm) & $30-40$ & 41 \\
\hline Lebar Peduncle $(\mathrm{cm})$ & $4-4.5$ & 3.5 \\
\hline Warna Peduncle & Hijau Tua & Hijau \\
\hline Posisi Rachis & Falling vertically & Falling vertically \\
\hline Tipe Jantung Pisang & Normal & Normal \\
\hline Bentuk Jantung Pisang & Intermediate & Ovoid \\
\hline Bentuk Ujung Braktea & Obtuse & Obtuse and split \\
\hline Warna Permukaan Luar Braktea & Merah Keungguan & Merah Keungguan \\
\hline Warna Ujung Braktea & Tinted with yellow & Tinted with yellow \\
\hline Jumlah Braktea yang terbuka & Dua atau lebih & Satu \\
\hline Keadaan Braktea Sebelum Jatuh & Tidak Menggulung & Tidak Menggulung \\
\hline Warna Tepal Majemuk & Cream & Cream \\
\hline Pigmentasi Pada Tepal Majemuk & Tanpa Pigmentasi & Pink \\
\hline Warna Lobe pada Tepal Majemuk & Kuning & Kuning \\
\hline Warna Tepal Bebas & Translucent white & Translucent white \\
\hline Bentuk Tepal Bebas & Oval & Oval \\
\hline Bentuk Ujung Tepal Bebas & Triangular & Triangular \\
\hline Kedudukan Style Terhadap Tepal Majemuk & Sama Tinggi & Lebih Tinggi \\
\hline Bentuk Style & Lurus & Melengkung Pada bagian Pangkal \\
\hline Bentuk Ovary & Lurus & Lurus \\
\hline Jumlah Buah dalam satu sisir & $7-14$ & 13 \\
\hline Panjang Buah $(\mathrm{cm})$ & $6-7$ & 9 \\
\hline Bentuk Buah & Straight & Straight \\
\hline Bentuk Ujung Buah & Lengthily pointed & Blunt-tipped \\
\hline Remains of flower relicts & Persistent style & Base of the style prominent \\
\hline
\end{tabular}



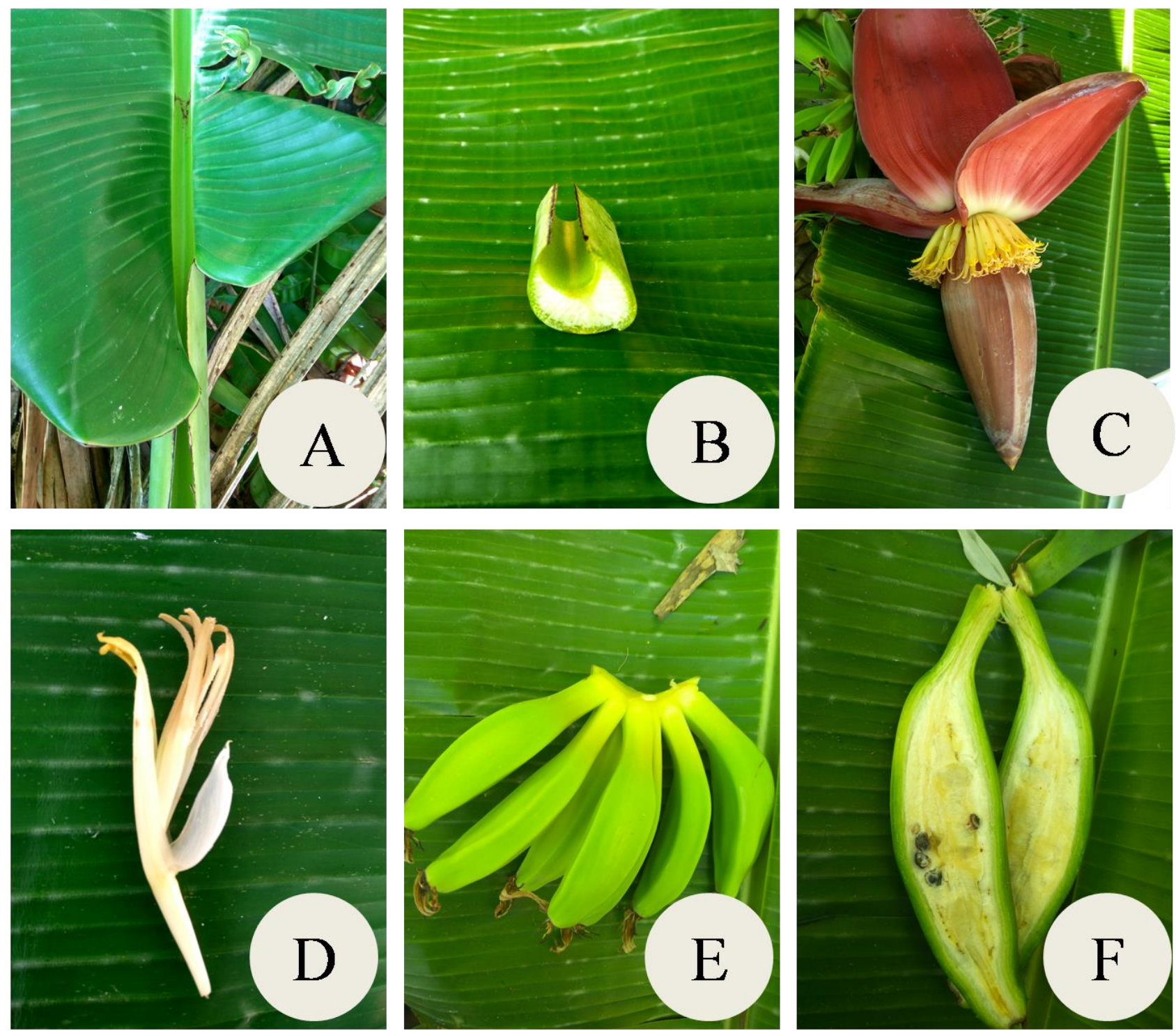

Gambar 1. Foto karakter morfologi Musa balbisiana (diploid).

A. Pangkal daun, B.Petiole, C. Jantung Pisang, D. Bunga jantan, E. Sisir pisang, F. Potongan membujur buah pisang
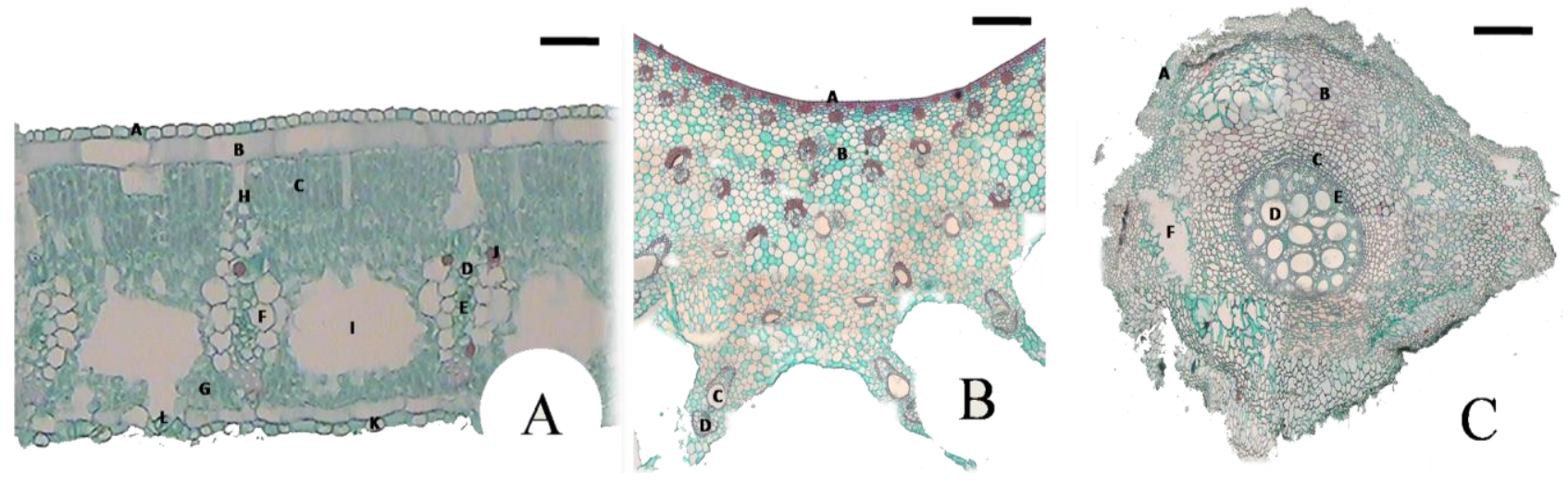

Gambar 3. Foto struktur anatomi Musa paradisiaca 'Kepok' (triploid).

Daun (A) :a, adaxial epidermis; b, hypodermis; c, jaringan palisade ; d, xylem; e, phloem; f, bundle sheath; g, jaringan bunga karang; h, sclerenchyma; i, rongga udara; j, laticifer; k, abaxial epidermis; l, stomata. Petiole (B) :a, epidermis; b, parenchyma cells; c, xylem; d, phloem. Akar (C):a, epidermis; b, cortex; c, endodermis; d, vessel; e, phloem; f, aerenkim. Bar $=100 \mu \mathrm{m}$. 

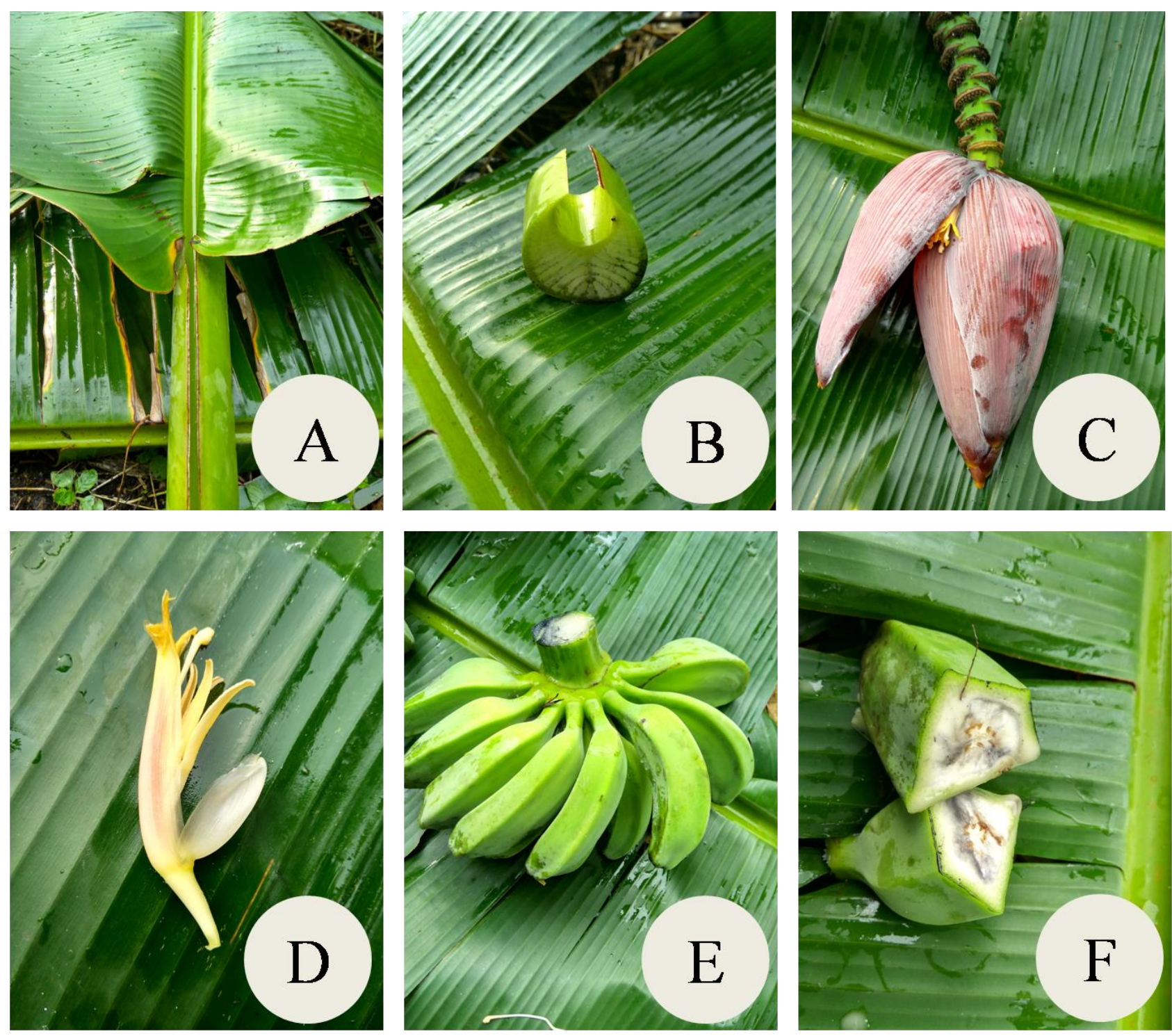

Gambar 2. Foto karakter morfologi Musa paradisiaca 'Kepok' (triploid)

A. Pangkal daun, B. Petiole, C. Jantung pisang, D. Bunga jantan, E. Sisir pisang, F. Irisan melintang buah pisang
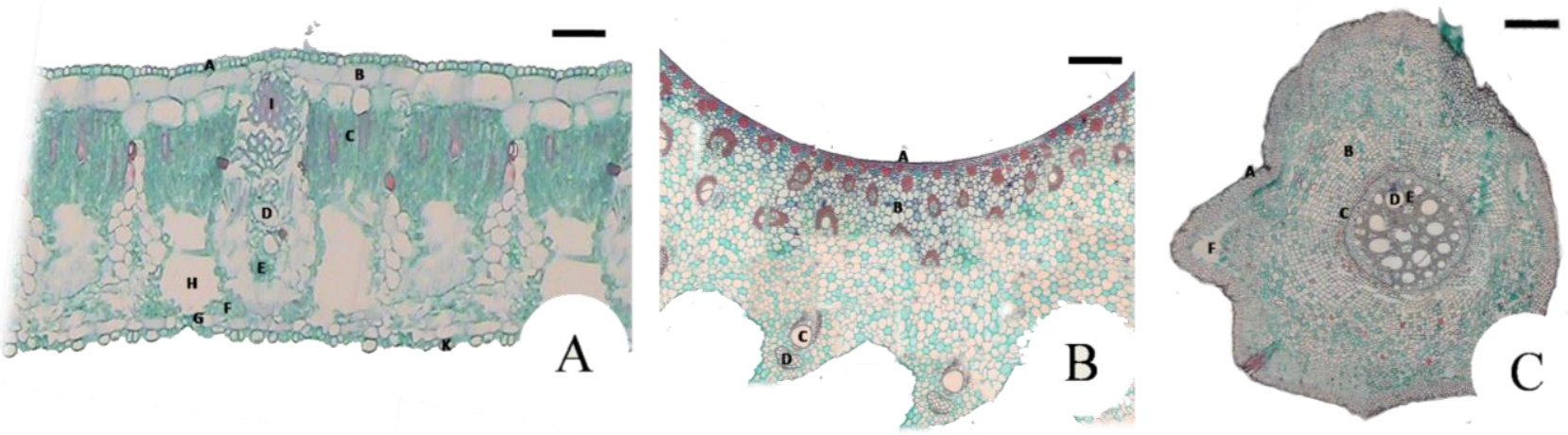

Gambar 4. Foto struktur anatomi Musa balbisiana (diploid).

Daun (A) :a, adaxial epidermis; b, hypodermis; $c$, jaringan palisade ; d, xylem; e, phloem; f, jaringan bunga karang; g, stomata; h, rongga udara; i, sclerenchyma; j, laticifer; k, abaxial epidermis. Petiole (B) :a, epidermis; b, parenchyma cells; c, xylem; d, phloem. Akar (C):a, epidermis; b, cortex; c, endodermis; d, vessel; e, phloem; f, aerenkim. Bar $=100 \mu \mathrm{m}$

Pisang kepok memiliki kulit yang tebal, berwarna kuning dengan bintik coklat yang gelap. Morfologi buah pisang kapok sangat tidak menarik, buah perlu dimasak dahulu sebelum dikonsumsi dan memiliki rasa buah yang tidak terlalu manis (Hapsari \& Lestari, 2016).
Secara anatomi, daun $M$. balbisiana dan $M$. paradisiaca 'Kepok' tersusun atas adaxial epidermis, hypodermis, palisade, bunga karang, bundle sheat cell, abaxial epidermis, dan laticifer. Sel epidermis M.balbisiana berbentuk bulat sedangkan sel epidermis M. paradisiaca 'Kepok' berbentuk persegi panjang. 
Jaringan hypodermis ditemukan pada sisi adaxial dan abaxial daun M. balbisiana dan M. paradisiaca 'Kepok'. M. balbisiana memiliki dua lapis jaringan hypodermis pada sisi adaxial dan satu lapis pada sisi abaxial. Sedangkan M. paradisiaca 'Kepok' memiliki satu lapis jaringan hypodermis pada sisi adaxial dan abaxial daun. Harijati et al., (2013) melaporkan bahwa jaringan hypodermis hanya ditemukan pada sisi adaxial daun M. paradisiaca 'Kepok'. Dua lapis jaringan hypodermis juga ditemukan pada $M$. paradisiacal 'Kluthuk Susu' (Sumardi \& Wulandari, 2010) dan $M$. paradisiaca 'Kepok' (Harijati et al., 2013). Tiga lapis jaringan hypodermis ditemukan pada $M$. branchyacarpa, M. sapietum dan $M$. cavendish (Harijati et al., 2013). Hypodermis yang tersusun atas 2 sampai 3 lapis merupakan karakter Musaceae (Tomlison, 1969). Jaringan hypodermis pada daun memiliki beberapa fungsi. Pada Musa sapientum, hypodermis berfungsi agar daun muda tidak menggulung (Skutch, 1930). Rundel et al., (1998) melaporkan bahwa jaringan hypodermis berfungsi untuk menurunkan kerusakan jaringan fotosintesis akibat cahaya matahari.

Jaringan mesofil pada daun disusun oleh jaringan palisade dan bunga karang. $M$. balbisiana dan $M$. paradisiaca 'Kepok' memiliki dua lapis jaringan palisade dan tersusun rapat (Gambar 3 dan 4). Dua lapis jaringan palisade juga ditemukan pada $M$. branchyacarpa dan M. sapietum (Harijati et al., 2013). Jaringan bunga karang pada $M$. balbisiana dan $M$. paradisiaca 'Kepok' memiliki bentuk sel yang tidak beraturan, yang berfusi membentuk aerenkim. Aerenkim pada $M$. balbisiana dan $M$. paradisiaca 'Kepok' terletak diantara dua berkas angkut. Kondisi ini juga ditemukan pada Penjalin, Kluthuk warangan, Ambon warangan, Raja nangka dan Kluthuk susu (Sumardi \& Wulandari, 2010), M. branchyacarpa, $M$. sapietum, $M$. paradisiaca 'Kepok' dan $M$. cavendish (Harijati et al., 2013) dan merupakan kondisi yang umum pada daun pisang (Tomlison, 1969).

Jaringan angkut ditemukan di mesofil. Berkas angkut pada $M$. balbisiana dan M. paradisiaca 'Kepok' terdiri atas xylem dan floem. Berkas angkut dikelilingi oleh sel sklerenkim. Berkas angkut yang dikelilingi oleh sel sklerenkin juga ditemukan pada Penjalin, Kluthuk warangan, Ambon warangan, Raja nangka dan Kluthuk susu (Sumardi \& Wulandari, 2010). Laticifer pada $M$. balbisiana dan $M$. paradisiaca 'Kepok' ditemukan berasosiasi dengan berkas angkut (Gambar 3 dan 4). Laticifer adalah sel atau kelompok sel yang berisi latek atau getah (Beck, 2010). Laticifer ditemukan di jaringan palisade dan berkas angkut (Sumardi \& Wulandari, 2010). Namun, laticifer juga dapat ditemukan di abaxial epidermis (Harijati et al., 2013).

Petiole M. balbisiana dan M. paradisiaca 'Kepok' disusun oleh tiga jaringan yaitu:jaringan epidermis, parenkim, dan berkas angkut. Jaringan epidermis pada M. balbisiana dan M. paradisiaca 'Kepok' tersusun atas satu lapis, kompak, dan berbentuk persegi panjang. Sel parenkim ditemukan pada bagian tengah petiole (Gambar 3 dan 4). M. acuminata 'Penjalin' and $M$. acuminata 'Ambon warangan' memiliki satu lapis sel epidermis yang berbentuk persegi panjang, kompak, dan dilindungi oleh kutikula. M. acuminata 'Penjalin' and $M$. acuminata 'Ambon warangan' juga memiliki sel parenkim yang terletak pada bagian tengah petiole, berbentuk seperti bintang dan terdapat rongga udara yang besar (Sumardi \& Wulandari, 2010).

Akar M. balbisiana dan M. paradisiaca 'Kepok' tersusun atas tiga jaringan yaitu:epidermis, parenkim, dan jaringan angkut. M. balbisiana dan M. paradisiaca 'Kepok' memiliki satu lapis jaringan epidermis. Satu atau dua lapis jaringan epidermis juga ditemukan pada $M$. acuminata 'Penjalin' and $M$. paradisiaca 'Raja Nangka' (Sumardi \& Wulandari, 2010). Aerenkim ditemukan pada akar M. balbisiana dan M. paradisiaca 'Kepok'. Adanya aerenkim yang terhubung dari tajuk hingga ke akar akan meningkatkan difusi oksigen dari daun ke akar akan mendukung proses respirasi (Evert, 2006). Aerenkim juga ditemukan pada M. acuminata 'Penjalin', M. balbisiana 'Kluthuk Warangan', $M$. acuminata 'Ambon warangan', dan M. paradisiaca 'Kluthuk', namun tidak ditemukan pada M. paradisiaca 'Raja Nangka' (Sumardi \& Wulandari, 2010).

Hasil penelitian ini menunjukan bahwa tanaman pisang dengan tingkatan ploidi yang berbeda, dalam hal ini $M$. balbisiana (diploid) dan $M$. paradisiaca (triploid) memiliki karakter morofologi dan anatomi yang berbeda pula.

\section{K E S I M P U L A N}

Tanaman pisang dengan tingkatan ploidi yang berbeda antara $M$. balbisiana diploid dan $M$. paradisiaca triploid menunjukkan perbedaan karakter morfologi pada tipe saluran pada petiole, bentuk pangkal daun, bentuk jantung pisang, bentuk ujung braktea, jumlah braktea yang terbuka, kedudukan style terhadap tepal bebas, bentuk style, bentuk ujung buah, dan sisa bagian bunga yang tertinggal pada buah, serta pada karakter anatomi pada jumlah lapisan hypodermis.

\section{DAFT AR REFERENSI}

Ahmad F, Megia R, Poerba YS. 2014. Genetic diversity of Musa balbisiana Colla in Indonesia based on AFLP marker. Hayati Journal of Biosciences. 21(1):39-47.

Beck C. 2010. An Introduction to Plant Structure and Development. Cambridge (Second Edi.). New York: Cambridge University Press.

Evert R. 2006. Esau's Plant Anatomy: Meristems, Cells, and Tissues of The Plant Body: Their Structure, Function and Development (Third Edit). Canada: John Wiley \& Sons.

Hapsari L. 2014. Wild Musa species collection of Purwodadi Botanic Garden: Inventory and its morpho-taxonomic review. Journal of Tropical Life Science. 4(1):70-80

Hapsari L, Lestari DA. 2016. Fruit characteristic and nutrient values of four Indonesian banana cultivars (Musa spp.) at different genomic groups. Agrivita. 38(3):303-311

Harijati N, Azrianingsih R, Prawaningtyas EA. 2013. The Study of Anatomy and Fiber Banana Leaf as a Potensial Wrapping. American Journal of Plant Science. 4:1461-1465

International Plant Genetic Resources Institute. 1996. Description for Bananas (Musa spp). IPGRI, Rome

Johansen DA. 1940. Plant Microtecniques. London: Mc-Graw Hill Book Co. Inc 
Liu AZ, Kress WJ, Li DZ. 2010. Phylogenetic analyses of the banana family (Musaceae) based on nuclear ribosomal (ITS) and chloroplast (trnL-F) evidence. Taxon. 59 (1):20-28.

Megia R. 2005. Musa sebagai model genom. Hayati 12:167-170.

Padoan D, Mossad A, Chiancone B, Germana MA, Khan PSSV. 2013. Ploidy levels in Citrus clementine affects leaf morphology, stomatal density and water content. Theoretical and Experimental Plant Physiology. 25(4):283-290.

Retnoningsih A. (2009). Moleculer based classification and phylogenic analysis of Indonesian banana cultivars. [dissertation]. Bogor Agricultural Institute. Bogor.

Rundel PW, Sharifi MR, Gibson AC, Esler KJ. 1998. Structural and physiological adaptation to light environments in neotropical Heliconia (Heliconiaceae). Journal of Tropical Ecology. 14(6):789-801.

Shokefun EO, Ayodele AE, Akinloye AJ. 2016. Systematic importance of leaf anatomical characters in some species of Microcos Linn. Section Eumicrocos Burret. in Nigeria. American Journal of Plant Sciences. 7:108-117.
Skutch AF. (1930). Unrolling of Leaves of Musa sapientum and Some Related Plants and Their Reactions to Environmental Aridity. Botanical Gazette. 90(4):337-365.

Silva NK, Agra MF. 2011. Leaf epidermal characters of Solanum sect. Polytrichum (Solanaceae) as taxonomic evidence. Microscopy research and technique. 74:1186-1191

Simmonds NW, Shepherd K. 1955. The taxonomy and origins of the cultivated bananas. Journal of Linnean Society Botany. 55:302312 .

Simmonds NW. 1966. Bananas. New York: Longman Inc

Sulistyaningsih LD, Megia R, Widjaja EA. 2014. Two new record of wild bananas (Musa balbisiana and Musa itinerans) from Sulawesi. Makara J Sci. 18 (1):1-6.

Sumardi I, Wulandari M. 2010. Anatomy and morphology character of five Indonesian banana cultivars (Musa spp.) of different ploidy level. Biodiversitas, 11(4), 167-175.

Tomlison PB. (1969). Anatomy of Monocotyledons. Clarendron. Oxford. 